\title{
RIVER RESTORATION FOR THE REPLACEMENT OF LOST SPAWNING GROUNDS DUE TO DAM CONSTRUCTION
}

\author{
REGINA SANTOS ${ }^{1,2}$, LUÍS SANCHES FERNANDES ${ }^{1}$, FERNANDO PACHECO ${ }^{2}$, \\ MARIZA MONTEIRO ${ }^{1} \&$ JOAQUIM JESUS $^{1}$ \\ ${ }^{1}$ Centre for the Research and Technology of Agro-Environment and Biological Sciences, \\ University of Trás-os-Montes and Alto Douro, Portugal \\ ${ }^{2}$ Chemistry Research Centre, University of Trás-os-Montes and Alto Douro, Portugal
}

\begin{abstract}
The construction of Baixo Sabor Hydroelectric Scheme (BSHS) in the Sabor River (located in northeast Portugal) without fishways has blocked fish migration. However, the Vilariça River, a tributary of the Sabor River, located downstream of BSHS represents an alternative habitat for fish, especially for specie more abundant in this river, the potamodromous cyprinid Iberian barbel (Luciobarbus bocagei). This way, to replace the spawning grounds lost in Sabor River, several compensation measures were implemented in a $2 \mathrm{~km}$ long river stretch of the Vilariça River. The measures included restoration activities like bank reinforcement, boulder placement, river water profile increase, and placement of submerged weirs with fish ramps to increase the lotic/lentic sequence. The river water profile increase was done with an adductor system constructed to transfer water from the BSHS to upstream the $2 \mathrm{~km}$ long river stretch during spawning. In the river stretch, a River Connectivity Index (RCI) was used and sampling sites of the Iberian barbel were set on to assess the effect of the compensation measures. The RCI and the wetted perimeter method showed that the water velocity of $1.5 \mathrm{~m}^{3} / \mathrm{s}$ provides good longitudinal connectivity. The results showed that barbel spawns preferentially in a coarse substrate with shallow water and moderate water velocity. The monitoring of the effectiveness of restoration measures during the first 6 years of exploration (2016-2020) showed that the major actions were well achieved, such as the importance of adductor system for attracting the breeding barbels to the river, the stabilization of the riverbank and the increase in the habitat heterogeneity. However, some structures must be intervened, like the replacement of the stone weir destroyed, replantation of native species, and the removal of exotic plants.
\end{abstract}

Keywords: river restoration, spawning grounds, dam construction, adductor system, Iberian barbel.

\section{INTRODUCTION}

One of the main impacts associated with the construction of the Baixo Sabor Hydroelectric Scheme (BSHS) is the barrier effect that prevents the migration of fish species such as the Iberian barbel (Luciobarbus bocagei) potamodromous cyprinid, which carry out significant migrations from the Douro River to the Sabor River. The establishment of a compensation measure for its conservation is justified by the great migratory movement for spawning that occurred before the construction of the BSHS. The fact that the Vilariça River is a tributary of the Sabor River and is located downstream of BSHS has the requirements for implementing compensation measures for lost habitat. This way, a river stretch of the $7 \mathrm{~km}$ long in the Vilariça River was restored to create adequate conditions for the reproduction of the fish species affected by the construction of the BSHS in the Sabor River. However, the interventions occurred with a greater incidence in the last $2 \mathrm{~km}$, and for this reason the present work describes the interventions carried out in this river stretch.

In the Vilariça River, the native species more abundant is the Iberian barbel, an excellent indicator of ecological quality and environmental degradation due to their abundance in wellpreserved Iberian rivers [1]. Due to their sensitivity to habitat changes, cyprinids are among the most endangered species in Europe as a result of increased river degradation. In this way, 
information on the behaviour, migration and spawning of these species is essential for the success of the requalification actions [2]. As well as the assessment of fluvial connectivity to improve the migratory movement to the spawning areas. According to Solà et al. [3] the River Connectivity Index (RCI) can be applied to any river hydraulic infrastructure that constitutes an obstacle to the longitudinal movements of the Ichthyofauna and it can be used as a complementary element in hydromorphological condition assessment.

In addition, the study area is important for the conservation of the environment because the Sabor River is part of the Natura 2000 Network, within the Special Protection Area (SPA) and the Sites of Community Importance (SCI), which are classified under European Directives 79/409/EEC and 92/43/EEC, respectively.

The main objective of this work is to improve the habitat quality in the Vilariça River for supporting the barbel migration and reproduction. For that, it is necessary (i) to assess fluvial connectivity of the restoration measures that have been implemented; (ii) to determine the optimal discharge from the adductor system to improve the migration routes and conserve spawning grounds; and (iii) to identify the environmental factors that support spawning activity.

\section{MATERIAL AND METHODS}

\subsection{Study area}

The Vilariça River (located in northeast Portugal) is a medium-sized and third-order stream [4] located on the right bank of the Sabor River, whose mouth is located downstream of BSHS. The section under the study of $2 \mathrm{~km}$ long in the Vilariça River is located immediately before at the confluence with the River Sabor (Fig. 1). The Vilariça River basin covers an area of $324 \mathrm{~km}^{2}$ with an altitude that ranged between $1,186 \mathrm{~m}$ in the mountains and $94 \mathrm{~m}$ in the convergence with the Sabor River [5]. In lower altitude the basin is occupied by agricultural areas ( $42 \%$ of the basin area), artificial areas $(2 \%)$ and water bodies $(1 \%)$ and in higher elevation the land use dominant is semi-natural areas $(31 \%)$ and forest $(25 \%)$, according to Land Use Land Cover of 2015 [5].

The riparian gallery, limited to a small strip on the banks, is dominated by Populus nigra, clusters of Salix salviifolia and Fraxinus angustifolia, and the presence of the non-native giant cane (Arundo donax) that invades some areas [6]. The climate is characterised by warm and dry summers and cold and wet winters. The annual precipitation is an average of 730 $\mathrm{mm} /$ year and occurred mostly in winter [7]-[9]. The average water temperature between 1993 and 2017 was $18.8^{\circ} \mathrm{C}$ and $22.3^{\circ} \mathrm{C}$ in spring and summer, respectively [9], [10]. The BSHS consists of two hydroelectric dams, the Baixo Sabor Dam and the Feiticeiro Dam located at $12.6 \mathrm{~km}$ and $3 \mathrm{~km}$ upstream of the confluence of the Douro river, respectively. The total energy produced with the contribution of pumping is $444 \mathrm{GWh}$ [11].

\subsection{River restoration measures}

To improve the reproduction habitat of fish species several restoration measures were implemented in the $2 \mathrm{~km}$ long river stretch of the Vilariça River (Fig. 1(c)). The restoration measures were carried out throughout 2014 and consisted of constructing an adductor system and improving channel hydromorphology and riverbank. The adductor system, called SaborVilariça, was constructed for transferring water from the BSHS to upstream of the $2 \mathrm{~km}$ long river stretch of the Vilariça River. From the adductor system was release the experimental flows of $1.0 \mathrm{~m}^{3} / \mathrm{s}, 1.25 \mathrm{~m}^{3} / \mathrm{s}, 1.5 \mathrm{~m}^{3} / \mathrm{s}$ and $2.0 \mathrm{~m}^{3} / \mathrm{s}$. The adductor is composed of a reinforced 

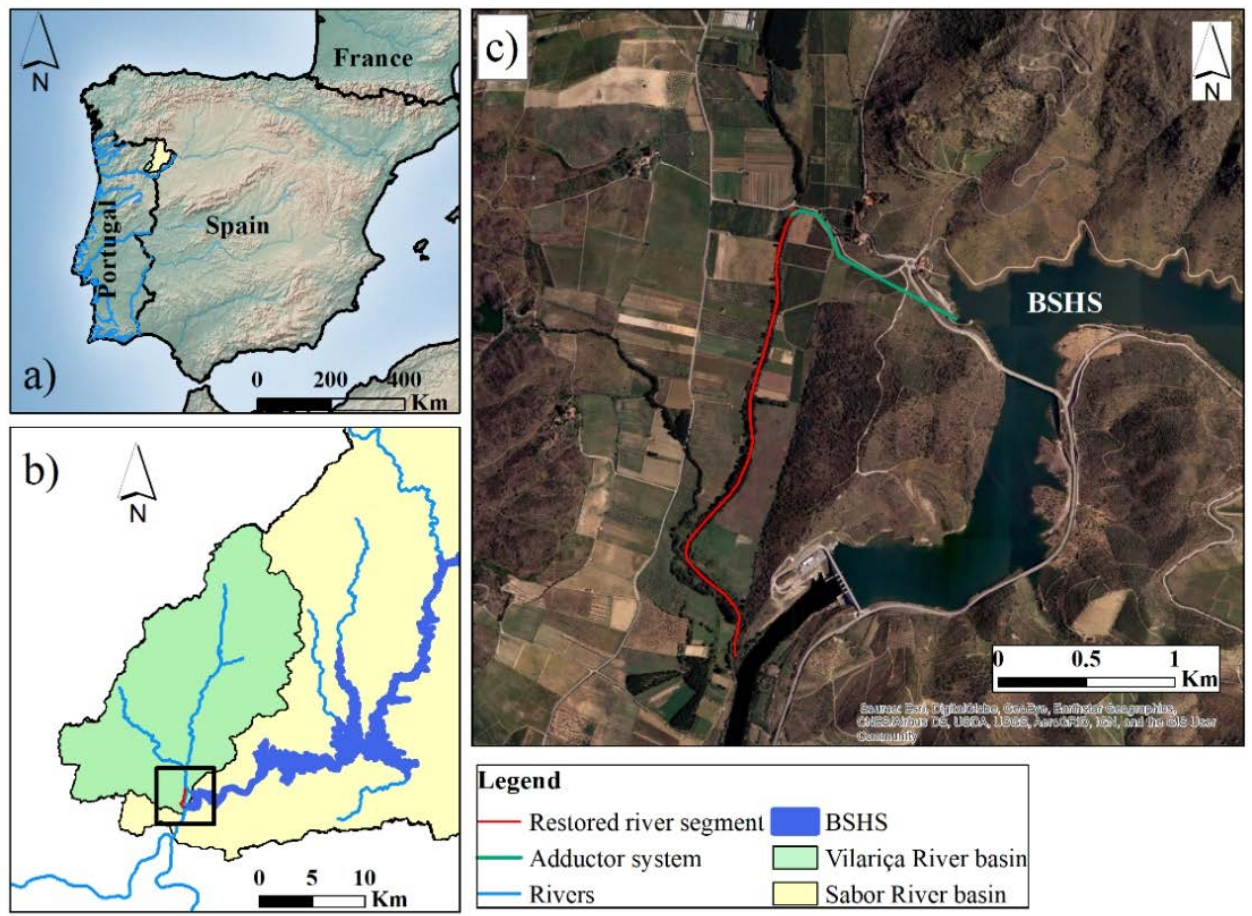

Figure 1: Location of the study area. (a) The Iberian Peninsula and the Sabor River in northern Portugal; (b) The Vilariça River and the Baixo Sabor Hydroelectric Scheme in the Sabor River; and (c) The restored river segment of $2 \mathrm{~km}$ long in the Vilariça River.

concrete structure, which is about $1000 \mathrm{~m}$ long, with safety gates and flow control. The flow passes in the adductor, in free surface and, in the terminal phase, in a transition structure with macro roughness for energy dissipation and finally, the flow enters in the Vilariça River by a restitution structure [12].

The channel hydromorphology interventions included the removal of fines in the riverbed, placement of blocks in the river and the construction of six transversal structures (weirs), six refuges structures with woody material (lunkers) and two islands planted with willow. The six transversal structures consist of two block stone weirs with rocky ramps and four large woods formed by trees trunks with central notches (Table 1). Due to the destruction of one of the large wood, it was later substituted by a deflector. The length of the five transversal structures varies between 7.1 and $17.9 \mathrm{~m}$ and the spillway between 1.25 and $3 \mathrm{~m}$, being that in large woods the location of the spillway is central, and in stone weirs are in the right bank. And finally, the interventions on the riverbanks consisted of planting native species, removing the non-native giant cane and constructing vegetated riprap and vegetated gabion with live willow cuttings for bank protection [12]. The implemented restoration measures were continuously monitored from 2016 to 2020 [13].

To evaluate the level of transposability of the transversal structures was used the River Connectivity Index (RCI) applied for the natural flow $\left(0.57 \mathrm{~m}^{3} / \mathrm{s}\right)$ and the experimental flows 
Table 1: Characteristics of the transversal structures placed in the $2 \mathrm{~km}$ long river stretch of the Vilariça River to improve the quality of the fish habitat.

\begin{tabular}{|l|c|c|c|c|}
\hline Transversal structure & $\begin{array}{c}\text { Length } \\
(\mathrm{m})\end{array}$ & $\begin{array}{c}\text { Spillway } \\
(\mathrm{m})\end{array}$ & $\begin{array}{c}\text { Location of } \\
\text { spillway }\end{array}$ & $\begin{array}{c}\text { Type of } \\
\text { obstacle RCI }\end{array}$ \\
\hline Large wood E1 & 7.1 & 1.25 & Central & A \\
\hline Deflector E2 & 9 & n.a. & Central & n.a. \\
\hline Large wood E3 & 15.7 & 1.3 & Central & A \\
\hline Stone weir E4 & 13.5 & 2.5 & Right bank & C \\
\hline Large wood E5 & 13.8 & 1.5 & Central & A \\
\hline Stone weir E6 & 17.9 & 3 & Right bank & C \\
\hline
\end{tabular}

Note: n.a. $=$ not applicable.

released from the adductor system. In structures in which water passes over the obstacle (weir type) creating a small waterfall (type A), the parameters measured are the following: Tw width of spillway crest (m); Tz - water depth under spillway crest $(\mathrm{m}) ; \mathrm{h}$ - the difference level between the spillway crest and the water level immediately downstream of the weir $(\mathrm{m})$; and $\mathrm{z}$ - water depth immediately downstream of the weir $(\mathrm{m})$. In structures with a very low slope, where water passes over the obstacle and does not generate any waterfall (type C) the longitudinal slope $(\%)$ and the average runoff speed $(\mathrm{m} / \mathrm{s})$ were evaluated [3].

The final RCI score obtained varies between 0 and 110 and obstacles are classified into 5 quality classes: $\geq 95$ correspond to very good quality (all the present groups of fish can pass); 75-94 good (the majority of the present fish groups can pass); 50-74 moderate (the majority or some of the present fish groups can pass); 25-49 poor (only one or few species of the present groups of fish can pass) and $<25$ bad (no species of the present groups of fish or only some in very exceptional hydrological situations can pass) [3]. In the large wood, the RCI index calculation was used based on the type A obstacle and in the stone weir the type $\mathrm{C}$ obstacle (Table 1).

\subsection{Wetted Perimeter Method}

The Wetted Perimeter Method was used to obtain submerged habitat (and theoretically available for the fishes) given by the Wetted Perimeter and the flow. The fieldwork was developed in three representative sections on barbel habitat during the reproduction period (between April and July of 2015). This method is based on a comparative analysis between the flows in a section of a watercourse and the corresponding wetted perimeters, assuming that there is a relationship between both. The method requires that for the section of a watercourse, the curve that relates the flows with the respective wetted perimeters is obtained to determine the hydraulic conditions in which the spawners are found. Therefore, the wetted perimeters were obtained for the natural flow $\left(0.57 \mathrm{~m}^{3} / \mathrm{s}\right)$ and the flow released from the adductor system $\left(1.0,1.25,1.5\right.$ and $\left.2.0 \mathrm{~m}^{3} / \mathrm{s}\right)$.

\subsection{Spawning grounds identification}

In the $2 \mathrm{~km}$ long river stretch, between April and July 2015, the spawning grounds of barbel were identified to know the most suitable habitat for the eggs deposition. Therefore, an evaluation of the hydraulic parameters as water depth, current velocity, granulometry of the substrate and cover were carried out. The water depth and the current velocity were measured with an electromagnetic reel and the percentage of substrate and cover were determined 
visually. The substrate was assessed using a modified Wentworth scale: 0 - organic material detritus; 1 - silt, clay, loam (1-2 mm); 2 - sand ( $<2 \mathrm{~mm}) ; 3$ - fine gravel $(2-6 \mathrm{~mm}) ; 4-$ medium gravel $(6-20 \mathrm{~mm}) ; 5$ - large gravel $(2-6 \mathrm{~cm}) ; 6$ - small stones $(6-12 \mathrm{~cm}) ; 7$ - large stones $(12-20 \mathrm{~cm}) ; 8$ - boulders $(>20 \mathrm{~cm})$; and 9 - rock [14].

\section{RESULTS AND DISCUSSION}

\subsection{River restoration measures}

The habitat restoration was implemented in the $2 \mathrm{~km}$ long river stretch of the Vilariça River for increasing habitat heterogeneity and improving fish migration and spawning beds. The restoration measures included the increase of the water volume and current speed in the river segment of $2 \mathrm{~km}$ long, through the construction of the adductor system between the BSHS and the Vilariça River to transfer water during the reproduction period of the native ichthyofauna (from 15 March to 31 July) (Fig. 2(a)).
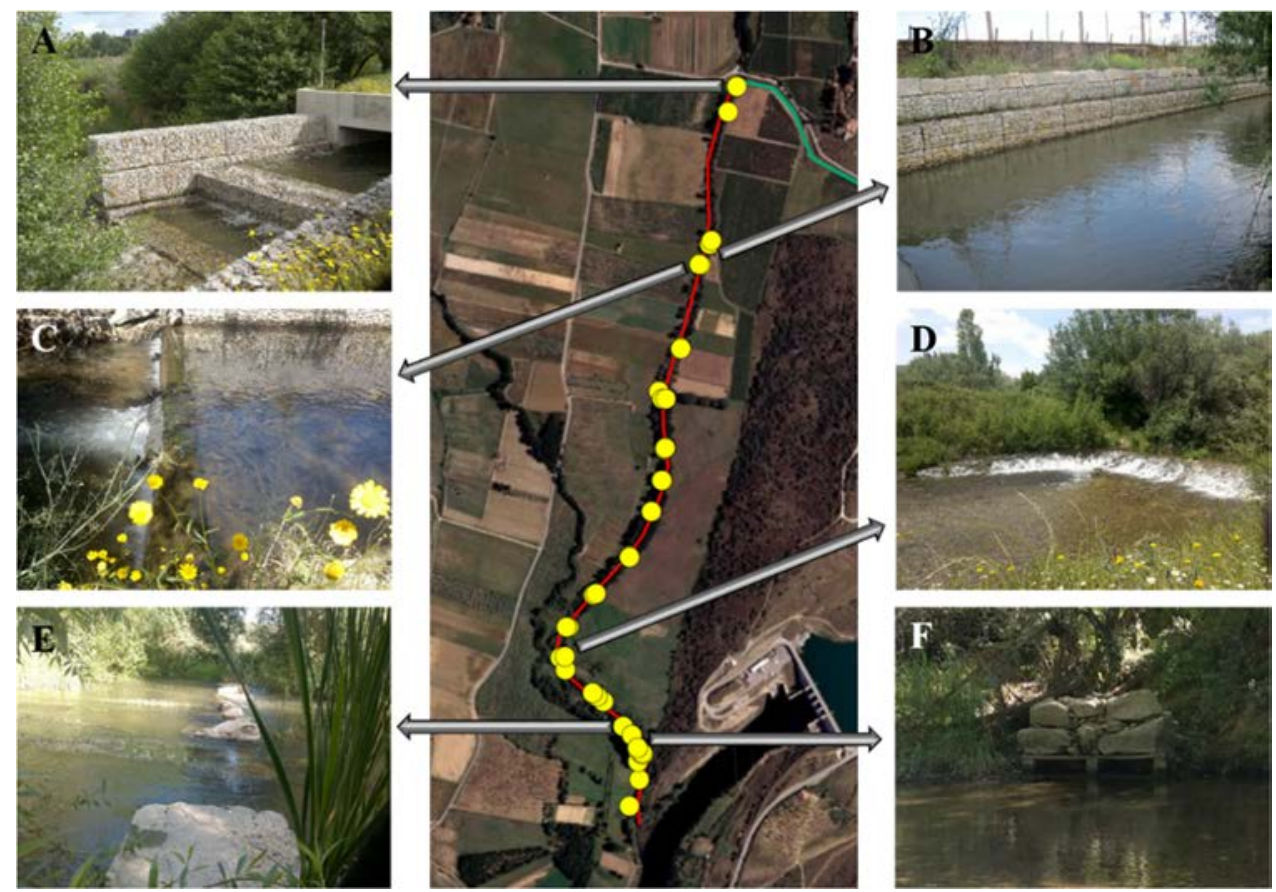

Figure 2: Examples of interventions implemented in the $2 \mathrm{~km}$ long river stretch of the Vilariça River to improve fish habitat. (a) Adductor system; (b) Reinforcement of the riverbanks with vegetated gabions; (c) Weir of the large wood; (d) Stone weir; (e) Placement of blocks in the riverbed; and (f) Lunkers.

In the riverbank, the restoration actions included the plantation of the native species (with live stakes willow), the removal of non-native giant cane followed by the reinforcement by vegetated riprap, and vegetated gabions with live stakes of willow (Fig. 2(b)). The reinforcement of the riverbank was applied for the consolidation of embankments in places with a marked erosion process. 
The interventions in the channel hydromorphology consisted in the construction of three weirs of the large wood in slope areas not exceeding $5 \%$ to promote a sequence of riffles and pools for improving the water quality by decreasing the concentration in total suspended solids and consequently promoting the sedimentation of fines and the heterogeneity of the microhabitat (e.g. forming lotic/lentic sequence and with different substrate granulometry); (Fig. 2(c)); the construction of two stone weirs for creating a habitat that allows housing native fish populations, breeding adults and juveniles, especially during the dry season (Fig. 2(d)); the placement of blocks in the riverbed to create hydraulic irregularity and substrate heterogeneity, current speed and cover in the bed of the watercourse, promoting new zones of refuge for fish (Fig. 2(e)), the construction of six lunkers with woody material for refuge for fish fauna (Fig. 2(f)), as well as the construction of two islands planted with willow and the removal of fines in the riverbed.

The level of transposability of the transversal structures determined by the River Connectivity Index for the natural flow and the flow released from the adductor system are presented in Table 2. The results showed that all flows presented a good transposability, exception the flow of $0.57 \mathrm{~m}^{3} / \mathrm{s}$ (natural flow), in which the flow takes place in a small part of the transversal structures and may cause difficulties in the downstream migration.

Table 2: Classification of the River Connectivity Index of transversal structures for natural flow $\left(0.57 \mathrm{~m}^{3} / \mathrm{s}\right)$ and the flows released from adductor system $(1.0,1.25,1.5$ and $\left.2.0 \mathrm{~m}^{3} / \mathrm{s}\right)$. The RCI score between 75-94 represent good quality and between 5074 moderate quality.

\begin{tabular}{|c|c|c|c|c|c|}
\hline Flow $\left(\mathrm{m}^{3} / \mathrm{s}\right)$ & Large wood E1 & Large wood E3 & Weir E4 & Large wood E5 & Weir E6 \\
\hline 0.57 & 60 & 85 & 60 & 85 & 60 \\
\hline 1 & 85 & 85 & 85 & 85 & 85 \\
\hline 1.25 & 85 & 85 & 90 & 85 & 90 \\
\hline 1.5 & 85 & 85 & 90 & 85 & 90 \\
\hline 2 & 85 & 85 & 90 & 85 & 90 \\
\hline
\end{tabular}

\subsection{Relationship between flow and wetted perimeter}

The exponential curves adjusted for the three sections analysed show an asymptote of approximately $1.5 \mathrm{~m}^{3} / \mathrm{s}$ (Fig. 3). Thus, it can be considered that flows higher than $1.5 \mathrm{~m}^{3} / \mathrm{s} \mathrm{do}$ not represent significant increases in available habitat. This situation shows a river channel physically well delimited by relatively steep banks, as is typical of low-order rivers that run along plains.

\subsection{Spawning grounds}

Table 3 shows the characterization of the spawning grounds identified in the $2 \mathrm{~km}$ long river stretch as water depth, flow velocity, type of substrate and cover. In general, the barbel spawns essentially in places with low depth, moderate current, a substrate formed mainly by gravel and sand (with granulometry between 2 and $64 \mathrm{~mm}$ ) and preferably without any type of coverage. 

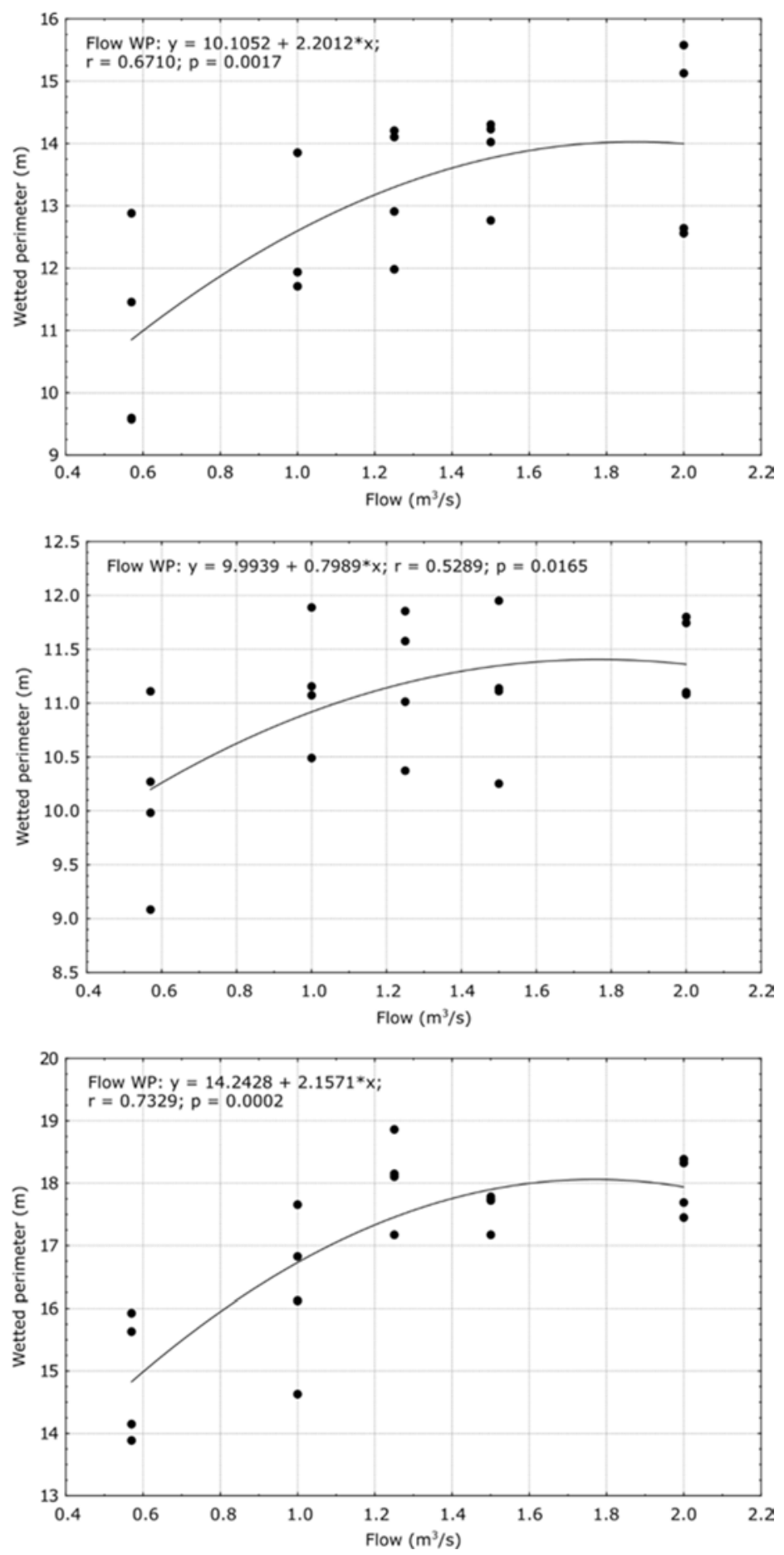

Figure 3: Relationship between wetted perimeter and flow with successive increments of about $0.5 \mathrm{~m}^{3} / \mathrm{s}$. 
Table 3: Characteristics of the spawning grounds in run and riffle habitat identified in the $2 \mathrm{~km}$ long river stretch of the Vilariça River.

\begin{tabular}{|c|c|c|c|c|c|}
\hline $\begin{array}{l}\text { Type of } \\
\text { habitat }\end{array}$ & $\begin{array}{l}\text { Number of } \\
\text { spawning } \\
\text { grounds }\end{array}$ & $\begin{array}{c}\text { Depth }(\mathrm{cm}) \\
\text { Mean } \\
(\text { min-max) }\end{array}$ & $\begin{array}{l}\text { Flow velocity }(\mathrm{m} / \mathrm{s}) \\
\text { Mean (min-max) }\end{array}$ & Substrate (\%) & Cover $(\%)$ \\
\hline Run & 11 & $\begin{array}{c}40.73 \\
(25-63)\end{array}$ & $\begin{array}{c}0.427 \\
(0.047-0.66)\end{array}$ & $\begin{array}{c}82 \% \text { gravel, } \\
14 \% \text { sand and } \\
4 \% \text { stones }\end{array}$ & $\begin{array}{l}64 \% \text { riparian vegetation } \\
\text { and } 36 \% \text { no vegetation }\end{array}$ \\
\hline Riffle & 7 & $\begin{array}{c}31.14 \\
(18-48)\end{array}$ & $\begin{array}{c}0.678 \\
(0.453-0.924)\end{array}$ & $\begin{array}{c}50 \% \text { sand, } \\
43 \% \text { gravel } \\
\text { and } 7 \% \text { stones }\end{array}$ & $\begin{array}{l}86 \% \text { no vegetation and } \\
14 \% \text { riparian vegetation }\end{array}$ \\
\hline Total & 18 & $\begin{array}{c}37 \\
(18-63)\end{array}$ & $0.525(0.047-0.924)$ & $\begin{array}{l}67 \% \text { gravel, } \\
28 \% \text { sand and } \\
0.06 \% \text { stones }\end{array}$ & $\begin{array}{l}56 \% \text { no vegetation and } \\
44 \% \text { riparian vegetation }\end{array}$ \\
\hline
\end{tabular}

\subsection{Monitoring of the effectiveness of restoration measures}

The monitoring of the effectiveness of restoration measures was developed during 5 years (2016-2020) after the implementation measures in 2014. To evaluated the performance of the adductor system was measured the water quality in five sampling points, three located upstream and two downstream of the flow release from the adductor system. The parameters measured were: temperature, dissolved oxygen, rate of oxygen saturation, biochemical oxygen demand (CBO5), electrical conductivity at $200^{\circ} \mathrm{C}$ (average), pH, nitrates, ammoniacal nitrogen, and phosphates. In all sampling points, the water quality was good and reasonable according to the classification of the Water Framework Directive. The CPUE (catch per unit effort) of barbel, carried out using electric fishing at the reproduction period, showed that the barbel population remained without substantial variations with values between 1.5 and 2 individuals/minute in the 6 years of monitoring (2015-2020). Except in 2018 that there was a considerable increase with values greater than eight individuals/minute. These results show that the flow released by the adductor system of the $1.5 \mathrm{~m}^{3} / \mathrm{s}$, during the breeding season, has proved to be sufficient to attract the barbel to the Vilariça River.

In general, the built structures (transversal structures, blocks, and lunkers) in the $2 \mathrm{~km}$ long river stretch of the Vilariça River kept the main characteristics unchanged during the monitoring period. However, in 2020 some structures have shown to have their operationality affected concerning the function initially envisaged, namely the absence of the stone weir that was located near the mouth of the Vilariça River (E6). The destruction of this weir (due to floods) led to a decrease in water depth and consequently the emergence of some shelter structures for fish fauna (lunkers), which in the normal situation should have been submerged. However, the reconstruction of the stone weir E6 is already authorized by the authority and should be rebuilt in September this year (2021).

The enhancement measures of the riparian gallery as exotic control actions and planting native species have not been successful. The control of exotic species had an immediate effect of decreasing its cover, in 2014, but it was consistently increasing in following years since there was no removal of roots, followed by native plantations. The actions for planting native species showed, as of 2016, a mortality rate of around $100 \%$. The cleaning actions also proved to be inefficient, due to the high dynamics of the watercourse, which carries a lot of solid elements every year. Nevertheless, the slope stabilization actions were well achieved, 
and the riparian gallery suffers much fewer consequences in the event of higher and potentially destructive flows, keeping the margins stabilized. In general, riparian communities since 2014 have been acquiring greater structural complexity, justified by the increase in tree cover, but it presents some degradation with low richness and an increased area of non-native giant cane.

\section{CONCLUSION}

The habitat restoration was implemented in the $2 \mathrm{~km}$ long river stretch of the Vilariça River for increasing habitat heterogeneity and improving fish migration and spawning beds. The work of restoration implied the removal of exotic plants, plantation of native species, and the construction of vegetated gabions and vegetated riprap to the consolidation of the riverbank. As well as the construction of an adductor system to increase the flow to attract the breeding barbels to the river and the construction of lunkers, boulder placement, and transversal structures to increase habitat heterogeneity. The evaluation of transposability of the transversal structures determined by the River Connectivity Index and the Wetted Perimeter Method showed that $1.5 \mathrm{~m}^{3} / \mathrm{s}$ is the ideal flow for attracting the breeding barbels to the river. In fact, in the breeding period of the barbel, the preferential habitats are characterized by moderate currents, substrate composed of gravel and sand, greater luminosity, shallow waters, and beds more homogeneous.

The monitoring of the effectiveness of restoration measures developed during 5 years (2016-2020) showed good and reasonable water quality and that the release of $1.5 \mathrm{~m}^{3} / \mathrm{s}$ by the adductor system is sufficient to attract the barbel to the Vilariça River. Relatively to build structures near the mouth of the Vilariça River became unusable, namely, the destruction of the stone weir and the inefficiency of some lunkers due to the decrease in water depth caused by the destruction of the weir. Relatively to the enhancement measures of the riparian gallery were verified the mortality of planting native species, expansion of exotics, however, the actions of stabilization of the riverbank were well achieved.

\section{ACKNOWLEDGEMENTS}

This research received financial support from Portuguese Foundation for Science and Technology (FCT), Ministry of Science, Technology, and Higher Education (MCTES), European Social Fund (FSE) through NORTE 2020 (North Regional Operational Program 2014/2020) and European Union (EU) to Regina Santos (Grant: SFRH/BD/141503/2018) for article writing. The authors integrated in the CITAB Research Centre was funded by the National Funds of FCT under the project UID/AGR/04033/2020. The authors integrated in the CITAB research centre are also integrated in the Inov4Agro - Institute for Innovation, Capacity Building and Sustainability of Agri-food Production. The Inov4Agro is an Associate Laboratory composed of two R\&D units (CITAB \& GreenUPorto). For the author integrated in the CQVR was funded by National Funds of FCT under the projects UIDB/QUI/00616/2020 and UIDP/00616/2020. And finally, we want to thank a Gestão da Produção de Energia, S.A. (EDP) for providing the data for publication. EDP is an energy producing company that operates the BSHS and financed all the restoration measures carried out in Vilariça River. We would also like to express our thanks to the whole team of the River Ecology Laboratory from the University of Trás-os-Montes and Alto Douro for the fieldwork carried out. 


\section{REFERENCES}

[1] Martínez-Capel, F., Jalón, D.G., Werenitzky, D., Baeza, D. \& Rodilla-Alamá, M., Microhabitat use by three endemic Iberian cyprinids in Mediterranean rivers (Tagus River Basin, Spain ). Fish. Manag. Ecol., 16, pp. 52-60, 2009.

[2] Ovidio, B.M. \& Philippart, J.C., Movement patterns and spawning activity of individual nase Chondrostoma nasus (L.) in flow-regulated and weir-fragmented rivers. J. Appl. Ichthyol., 24, pp. 256-262, 2008.

[3] Solà, C. et al., Longitudinal connectivity in hydromorphological quality assessments of rivers. The ICF index: A river connectivity index and its application to Catalan rivers. Limnetica, 30, pp. 273-292, 2011.

[4] Strahler, A.N., Quantitative analysis of watershed geomorphology. Trans. Am. Geophys. Union, 38, pp. 913-920, 1957.

[5] DGT Directorate-General of Territory Online. http://www.dgterritorio.pt/. Accessed on: 6 Mar. 2021.

[6] Boavida, I., Jesus, J.B., Pereira, V., Santos, C., Lopes, M. \& Cortes, R.M., Fulfilling spawning flow requirements for potamodromous cyprinids in a restored river segment. Sci. Total Environ., 635, pp. 567-575, 2018.

[7] Santos, R.M.B., Sanches Fernandes, L.F., Cortes, V.M.R. \& Pacheco, F.A.L., Hydrologic impacts of land use changes in the Sabor River Basin: A historical view and future perspectives. Water (Switzerland), 11, 1464, 2019.

[8] Santos, R.M.B., Sanches Fernandes, L.F., Cortes, V.M.R. \& Pacheco, F.A.L., Development of a hydrologic and water allocation model to assess water availability in the Sabor River Basin ( Portugal ). Int. J. Environ. Res. Public Health, 16, 2419, 2019.

[9] SNIRH National Information System for Water Resources Online. https://snirh.apambiente.pt/. Accessed on: 6 Mar. 2021.

[10] Santos, R.M.B., Monteiro, S.M., Cortes, R.M.V., Pacheco, F.A.L. \& Fernandes, L.F.S., Seasonal effect of land use management on gill histopathology of Barbel and Douro Nase in a Portuguese watershed. Sci. Total Environ., 764, 142869, 2021.

[11] AHBS Aproveitamento hidroelétrico do Baixo Sabor (Projecto), Apresentação à Comissão Executiva. EDP - Energias de Portugal. Torre de Moncorvo, p. 22, 2012.

[12] AHBS Aproveitamento hidroelétrico do Baixo Sabor. Medida compensatório MC1 Habitat de compensação da Vilariça. Laboratório de Ecologia Fluvial, Universidade de Trás-os-Montes e Alto Douro, Vila Real, p. 55, 2016.

[13] AHBS Aproveitamento hidroelétrico do Baixo Sabor, Relatório de monitorização da MC1 - Habitat de compensação da Vilariça. Fase de exploração (ano 2020). Laboratório de Ecologia Fluvial, Universidade de Trás-os-Montes e Alto Douro, Vila Real, p. 106, 2021.

[14] Bovee, K.D., Lamb, B.L., Bartholow, J.M., Stalnaker, C.B., Taylor, J. \& Henriksen J., Stream habitat analysis using the instream flow incremental methodology. U.S. Geologicial Survey, Biological Resources Division Information and Technology Report USGS/BRD-1998-0004, p. 143, 1998. 